\title{
Modern Design Education: Nurture in Technological Innovation and Social Responsibility
}

\author{
Zhiyong Wang \\ School of Arts, Sichuan University of Science and Engineering, Zigong, China
}

Email address:

matinee2005@aliyun.com

To cite this article:

Zhiyong Wang. Modern Design Education: Nurture in Technological Innovation and Social Responsibility. Science Journal of Education. Vol. 3, No. 4, 2015, pp. 85-88. doi: 10.11648/j.sjedu.20150304.13

\begin{abstract}
There is a strong interactive relationship between the education and the development of modern design. Every essential progress in design education had most probably encouraged a further development of modern design. The encouragement came not only from the educational practice, but also from the educational theory study which inevitably referred to the cultivating of design idea. As the establishment or the change of ideas could deeply influence the practice as well as the academic researching in modern design, the training of good thinking is revealing its importance in modern design education implementation. Here under a historical background of the evolution of modern design movements, it gives a general interpretation on the idea and practice of modern design education in the method of technological and ethical sociology, in which the application of technology to innovation and the sense of social responsibility draw a central attention comparatively, so as to present and clarify the meanings of the relationship between technology, society and design with the main objective of exhibiting the importance of technological innovation and social responsibility in the principles of modern design education.
\end{abstract}

Keywords: Modern Design, Education, Idea, Technological Innovation, Social Responsibility

\section{Introduction}

We should firstly have a comprehension on modern design if we want to have a total understanding of modern design education, for there is an obvious interactive relationship between them, and it is more obvious if we consider the fact that the former's technological and social characters had a strong influence on the latter. Broadly speaking, being once viewed as a direct social consequence of industrial revolution, modern design emerged in the beginning of twentieth century. But the historical process of modern design went along closely with the dramatic change of social and mental structures in western world, which is tagged now as the term: modernity [1]. Such a social change involved in many aspects, in which the political system, economical and manufacture technology, and even life-style were in this focus, and it gave the modern design a complicated feature not only in visual forms but also in ideas. In the beginning, modern movement of design (especially in England) refused industrialisation trends, but carried a democratic characteristics ("by the people, for the people" by William Morris). Then, the countries in European continent adopted industrial manufacture technology and standardisation. Deutscher werkbund declared firstly in history the slogan: the combination of technology and art. As a correspondence, it was followed by De Stijl in Netherland and Constructivism in Russia. Generally, as a whole, they put on modern design the features of industrialisation, functionalism and democracy, which all revealed its social and cultural meaning: science, technology, and utopia.

\section{Modern Design Education: A Historical Progress}

For the development of modern design was affected by the social changes which referred to technological innovation, economical system, or political revolution, we could found that modern design showed the multidisciplinary traits since beginning, as the compounded social factors provided a foundation for its evolving process. In these multidisciplinary characteristics, first of all, the industrial production technology played an impressive part in the shaping of modern design. It presented the new functional possibility from technology to design: industrialised type of design, in which a new aesthetical form appeared as well: it was called machine aesthetics, or industrial style. Within the new design model and aesthetics, the traditional decorative pattern had 
experienced a tendency of decline. If we considered the traditional decoration into a style of applied art, at least from a point view of visual form, modern design was once undergoing the vanishing of traditional art style. Contrarily, it created a new style. We could not ever look upon industrial production design as a handicraft: the aesthetical appreciation to the former is far away from to the latter. In The Sources of Modern Architecture and Design, the writer told us that the modern architecture and design for the public must be functionalised at first and it would never like to appreciate a chair which was used uncomfortable but only looked artistic [1]. Nevertheless, although industrial revolution has been seen as the result of technological innovation, it still implied the insurance of property rights and free market system [2] where the modern economy displayed itself. Moreover, at the similar period, modern western world had made a road towards political democracy and civil society. These factors performed powers not only in economical production field, but also spread their influences into every corner of western society where the design met the challenge again: design should also care the requirements from business market and the crises from the social management risk. So far, as industrial technology and style began to substitute the traditional handicraft and artistic taste, the economical and political ideology meaning of modern design was filled. As the whole, it was eagerly to call a new design education method and standard to meet the all needs from the told situation.

Bauhaus, as the first institution for modern design education, had once played a remarkable role in history. In the early days of its founding, Bauhaus bore the creator's utopia dream. From the origin of Bauhaus name ( bauhütten: a kind of guild in mediaeval age ) [3], we discovered the first chancellor Walter Gropius wished the school a mediaeval spirits with anti-individualism and cooperation. It rendered the initial stage of romanticised colour, and gave a preparation for the development of team working forms in the coming industrialised mass production trends however [4]. But the founder's utopia dream soon faced the cool reality, the early days' pro-artistic teaching method was failed to supply an efficient approach for modern design education within the industrial society. Then, the policymaker as Walter Gropius made a reformation: the new education way had the science, technology, and reasonable standardisation centralised. The result is, it became the most distinctive between the early traditional art school and Bauhaus, that the latter stressed heavily on industrial technology and functional design in teaching practice. Although having a utopian wish in the beginning and lacking of rationalism, Bauhaus finally established the industrial standardisation and functionalism as a main stream design education method. It was an important identity of design education's revolution. Under the tendency of social industrialisation, it was unavoidably necessary to bring the industrial technology utilisation into modern design teaching. For the industrial technology also represented the human's mental and behavioural reason, this new educational idea and approach reduced pure artistic training, but replaced with emphasising on function, reason and orders, which was eventually communicated by Bauhaus teachers' practices after the school reforming: Moholy Nagy changed the contents in his courses. He removed those which were associated with intuition, meditation or mystery. He suggested students to be familiar with technology and materials, to accept industrial skill and to use them in a reasonable way. Before, the students made traditional decorated candlestick and tea set in metal working studio, but now, Moholy Nagy advised them to create simple and practical electric lamps or tea cups. He had students use iron in stead of precious metals such as gold or silver. He wanted to educate the bran-new designers, who were capable of design by industrial production way [5].

A design history researcher gave the pertinent comments on Bauhaus reform, in which the team working, the rationalised teaching method and the practical considerations of design were in high light [6]. It was Bauhaus had the modern design education a scientific and reasonable basis. Furthermore, once design was industrialised, it could easily meet the needs from market: the public exhibition after Bauhaus education reform told the successful commercial reaction [6]. But we do not ignore Bauhaus experiments in its early age: utopian struggle strongly suggested the design and education could be an approach to social ideal and a possibility to reply the problems form the social realities.

\section{Nurture in Idea: Technological Innovation and Social Responsibility}

We have now a common view that modern design education does not merely equal to the training of specific skill, it however involved deeply in idea nurturing, for only idea could instruct designers using appropriate skills or techniques to resolve different problems. Without the guide of idea, the excellent skill could lose the way to creation and responsibility. But what kind of ideas should be the proper instructive one for modern design and education? Here we should concern initially again that modern design was a result of industrialisation and corresponded social evolution. The factors of social change made the design's modernity, where the nature science, industrial technology and social system shaped the modern life as well as modern design. Accordingly, in modern design education, especially in theoretical teaching practice, the relationship between modern social background and design will be taken into consideration in advance. Within this viewpoint, the role as technology and social responsibility at once indicate their importance.

The technological influences on design had a long history: a specific manufacturing technique in a particular historical period did manipulate the specific shape of design and its aesthetical form (known as styles or patterns). In the modern age so, the design form and its aesthetical appreciation strongly showed the key influence from modern technology and science. However, the significance of technology for design does not only imply the change of visual style or tastes, it will inevitably focus on the realistic work of problem solving. The solution for any design problem depends 
increasingly on the help of technology in the time of modern society, and it leads to more closed relationship between design and technological progress, which provides the crucial foundation of modern design innovation. As a result, in the training course of modern design, the technological factors rather than traditional artistic skills will be made in priority as an idea nurturing programme, for only with the supports of modern technology and science, design could creatively fulfill its functions in the industrialised world, which but can hardly be achieved by traditional artistic skill. (Fig.1)

\section{Technological Progress Design Innovation \\ Educational Idea of Technology and Innovation}

Figure 1. The relationship of technology and innovative design education.

The safety and convenience's innovative teaching and training of schoolhouse design, for instance, are definitively depended on architectural construction arrangement, ergonomics and material selection under the effective technological condition, but not ever firstly on artistic style or pattern.

Also, as the ethics is still a critical criterion for good design, we should strongly consider the social responsibility into the technology applications of modern design. If technology is value free, but the design's value and ideological critics are estimated inclinable to social morals and responsibilities. Within the moral consideration, we will put those public interests, such as social economic cost, energy saving or environmental protection, on our mind while designing procedure was taken. It forms another guideline to modern design education and teaching practice. (Fig.2)

Social Ethics Design Responsibility $>$ Educational Idea of Social Responsibility in Design

Figure 2. The relationship of ethics and design responsibility education.

A public bus design for example, should require an intensive thinking about systematic functions, in which an efficient way for passenger security (such as suitable emergency switch or hammer) will be the first important factor among them. But, if without full training and education the social responsible awareness for designer, a fatal harm caused by inapplicable design of emergency switch or hammer would be the most probable result in the unexpected dangerous situation. (Fig.3)

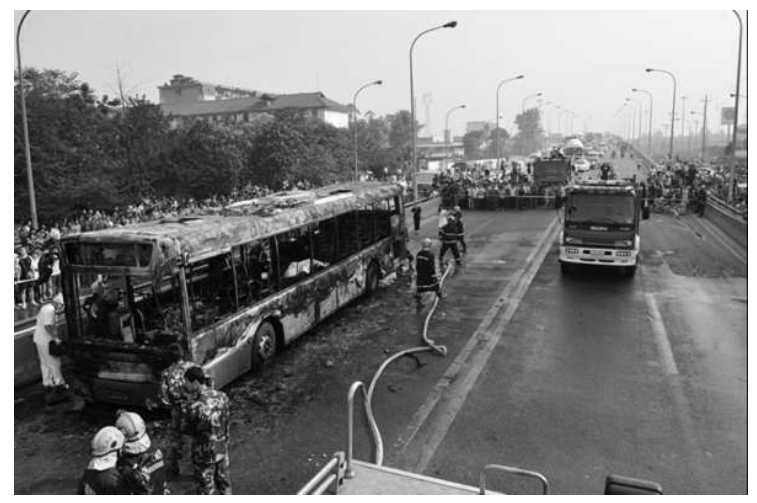

Figure 3. A bus fire disaster, Chengdu, China, 2009.

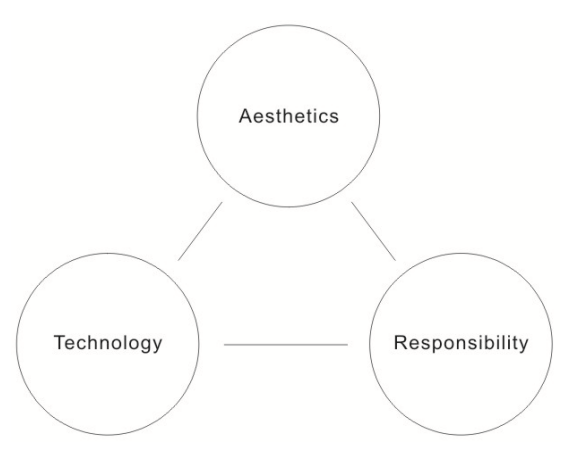

Figure 4. The principle guideline of modern design education.
As the consequence, here the three-dimensional principle thinking for modern design education is presented in following figure (Fig.4), which cared not only the aesthetical matters, but also the important functions from modern technology and responsibility:

With this kind of successful nurturing of idea in modern design education, the designers could master the corresponding multiple thinking, only which possessed the possibility to meet the needs and solve the problems from modern life. But we should also be aware that the multidisciplinary modern design education is always keep open for new changes, which keep the chance for design to cope with future technological revolution and moral issues. For example, the digital and internet technology, as the new impact on our daily life or social reform (even political reform), are challenging the design and its education again. All these still depend on the new design idea's establishment and nurturing.

\section{Conclusion}

Human's mentality is never the whipping top, it is active however. Idea acts as the forerunner for human behaviours and judgment. Therefore, the irrelevant idea in modern design will mislead the design activities, but only the proper idea will help the development of design and benefit the modern society. This is key reason why the idea nurturing in modern design education should be given a further intensive concerning. If the social problems or even suffering is a Lingering ghost, the modern designers should have the burden to deal with it seriously by modern technology and corresponding aesthetic forms. This very situation determines the design's role in modern age: modern design does not mean the garish visual patterns or fascinating styles, it indeed stands for rational and good functional approach or solutions for modern life. It again 
strongly suggests the scientific or technological thinking and social responsibility awareness as priority for modern designers, in stead of personal artistic expression.

\section{References}

[1] Nikolaus Pevsner, The sources of Modern Architecture and Design, translated by Yin Lingyun, SDX Joint Publishing Company, Beijing, 2001.

[2] Douglass C. North, Structure and Change in Economic History, translated by Li Yiping, The Commercial Press, Beijing, 1992.

[3] Andreas Haus, Bauhaus, edited by Jeannine Fiedler, Peter Feierabend, Könemann Verlagsgesellschft $\mathrm{mbH}$, Cologne, 2000, pp.14-21.

[4] Reyner Banham, Theory and Design in the First Machine Age, translated by Ding Yalei, Zang Xiao Ying, Phoenix Fine Arts Publishing. Ltd, Nanjing, 2009.
[5] Wu Huanjia, The Story of Western Modern Architecture, Baihua Publishing. Ltd, Tianjin, 2005.

[6] Wang Shouzhi, A History of Modern Design, China Youth Press, Beijing, 2002.

[7] Jesse S. Tatum, The Challenge of Responsible Design, Design Issue, 2004, 20 (No.3): pp.66-80.

[8] Gui Bonsiepe, Design and Democracy, Design Issue, 2006, 22 (No.2): pp.27-34.

[9] Victor Margolin, Design for development: towards a history, Design Studies, 2007, 28 (Issue.2): pp.111-115.

[10] Ezio Manzini, Making Things Happen: Social Innovation and Design, Design Issue, 2014, 30(No.1): pp.57-66.

[11] Picture resource: www.s1979.com. 